\title{
Engineering Students Learning Experience through a Unique Global Project-Based Learning
}

\author{
https://doi.org/10.3991/ijet.v16i15.24803 \\ Nurzal Effiyana Ghazali $\left.{ }^{1}{ }^{\bowtie}\right)$, Khairiyah Mohd. Yusof ${ }^{1}$, Fatin Aliah Phang ${ }^{1}$, \\ Rashidah Arsat ${ }^{1}$, Nur Azliza Ahmad ${ }^{2}$, Hiroaki Morino ${ }^{3}$ \\ ${ }^{1}$ Universiti Teknologi Malaysia (UTM), Malaysia \\ ${ }^{2}$ MAHSA University, Malaysia \\ ${ }^{3}$ Shibaura Institute of Technology (SIT), Japan \\ nurzaleutm.my
}

\begin{abstract}
Current students must prepare themselves with the necessary skills for employment in the engineering industry. In addition, students should prepare themselves to work globally. Along with the needs, Shibaura Institute of Technology introduces a program named global Project-Based Learning (gPBL). Malaysian students from different educational backgrounds joined this program to experience new skills. The program was participated by 34 students from Malaysia and Japan. Current engineering education is focusing on a course that can foster students' creativity and critical thinking. Therefore, this study explores students' experiences in gPBL and what student skills developed throughout the program. Students reported their experiences through the selfreflective journal. Then, thematic analysis was used to analyze the students' self-reflective journals. The results show gPBL promotes thinking and problemsolving skills, encourages students to work with peers in other fields, and encourages students to adapt to a new culture.
\end{abstract}

Keywords-Project-based learning, thinking skills, problem solving, crosscultural

\section{Introduction}

Higher education prepares students with $21^{\text {st }}$-century skills. $21^{\text {st }}$-century skills are the ability of the students to succeed in their careers. Three categories of the $21 \mathrm{st}$ learning century skills listed in [1] are cognitive competencies, interpersonal competencies, and intrapersonal competencies. Moreover, current higher education goes global to offer students cross-cultural activities and experiences.

Shibaura Institute of Technology (SIT) offers a platform to support $21^{\text {st }}$-century learning skills within the framework of the globalization and internationalization process. SIT had established 62 global Project-Based Learning (gPBL) groups around the world. gPBL program at SIT combines students from Japan and overseas partner universities working as tag teams to discuss and solve problems presented by professors, Japanese corporations, and organizations. This program is to encourage students 
to engage in acquiring problem-solving capabilities, system thinking, and systems management skills through this program [2]-[5].

The key features of project-based learning are driving questions, situated inquiry, collaboration, learning technologies, and artifacts [6]. In the aspect of engineering education, project-based learning is expected to enhance students' learning and innovation skills, digital literacy skills as well as career and life skills to manage future job and life demand.

\section{$2 \quad$ Related works}

Cognitivism addressed the role that environmental conditions influence the learning process. In cognitivism the instrument that guiding the learners such as instructional explanations, demonstrations, and illustrative examples. Jean Piaget, Reuven Feuerstein and Lev Vygotsky are contributors in cognitivism paradigm. The similarity of their theories is they believe centrality of cognition in child development, the emphasis of mental actions, and understanding of cognition as a structural system rather than a collection of separate skills. However, their theories have slightly different where Piagetian theory emphasizing the interaction between children and their environment, Vygotskian theory claim that mental growth depends on the internalization between cognitive functions while Feuerstein's theory is looking at the role of adults as a mediator of children's learning [7].

Feuerstein introduced the Theory of Mediated Learning Experience (MLE) which states that the quality of interaction between individual and environment via mediator influence cognitive development of the individual. The MLE principles are consistent with two major research areas which are metacognition and self-regulated learning.

The focus of this study is on metacognition. Flavell (1979) states that metacognition involves the interaction between an individual, a task, and the strategies used to accomplish the task. Even though Flavell predicts that the nature and the development of metacognition and cognitive monitoring was an interesting area to investigate in 1979 [8], there are a lot of studies until today on cognitive development [9]-[11].

According to Brown [12], there are two different terms in metacognition which are metacognitive knowledge and metacognitive strategies. Metacognitive knowledge defines as information that learners acquire about their learning whilst metacognitive strategies are general skills through which learners manage, direct, regulate and guide their learning [13]. According to Rahimi and Katal [10], metacognitive skills are applied in metamemory and meta comprehension. Table 1 provides an overview of the classification of metacognitive skills based on project-based learning [10], [11].

This study aims to explore the students' experiences in gPBL and what students' skills developed throughout the program. 
Table 1. Classification of Metacognitive Skills

\begin{tabular}{|c|c|c|}
\hline & Memory & Comprehension \\
\hline Schema training & $\begin{array}{l}\text { The subject has a variety of methods } \\
\text { available to help them recall the infor- } \\
\text { mation regarding their task and where they } \\
\text { found it. }\end{array}$ & $\begin{array}{l}\text { The subject has a variety of methods to } \\
\text { help them understand, monitor compre- } \\
\text { hension, and correct comprehension } \\
\text { failures on the task given. }\end{array}$ \\
\hline Planning & $\begin{array}{l}\text { The subject plans how they will record } \\
\text { their results and methods they learn along } \\
\text { the way. }\end{array}$ & $\begin{array}{l}\text { The subject plans to use a method to } \\
\text { monitor and improve their comprehension. }\end{array}$ \\
\hline Monitoring & $\begin{array}{l}\text { The subject assesses their sources for their } \\
\text { efficacy during task execution and changes } \\
\text { if necessary. }\end{array}$ & $\begin{array}{l}\text { The subject is aware of the extent to which } \\
\text { they are understanding from their reading } \\
\text { and appeal correction if necessary. }\end{array}$ \\
\hline Evaluation & $\begin{array}{l}\text { The subject critically evaluates their task } \\
\text { (success/failure) and use of memory strat- } \\
\text { egies and concludes future use. }\end{array}$ & $\begin{array}{l}\text { The subject critically evaluates their } \\
\text { comprehension and comprehensibility of } \\
\text { the task (success/failure) and concludes } \\
\text { future use. }\end{array}$ \\
\hline Transfer & $\begin{array}{l}\text { The subject carries learning from other } \\
\text { tasks into their decisions regarding how } \\
\text { they will remember information. The } \\
\text { subject carries learning from this task into } \\
\text { other tasks in the future. }\end{array}$ & $\begin{array}{l}\text { The subject carries learning from other } \\
\text { tasks into their decisions regarding how } \\
\text { they will monitor and improve their } \\
\text { comprehension. The subject carries learn- } \\
\text { ing from this task into other tasks in the } \\
\text { future. }\end{array}$ \\
\hline
\end{tabular}

\section{Design of the study}

The gPBL program was conducted in five days. Malaysian students and Japanese students were combined into seven groups which consist of four to five persons in a group. They had four days to complete the project, from 10th June 2019 until 13th June 2019 before presented their project on 14th June 2019. They were assigned the Internet of Things (IoT) for the project theme since it is the current trend of technologies as highlighted in red color in Figure 1.

The students were placed in a laboratory and have been provided with several sensors and microcontrollers as shown in Fig.2.

Based on the available equipment, the students started brainstormed a problem that they wanted to solve in their group. Postgraduate students were available as facilitators in the laboratory to help the students if they had any technical problems. Once the group has agreed to the problem that they wanted to solve, they started looking for a solution by finding information related to the problem and how to solve it using the available equipment.

During the process, students identified learning issues such as they need to know details about the problem. to look for more information related to the sensors that they had selected and working together in a new culture setting. The students completed the project through self-directed learning.

Participants of this study were students from Universiti Teknologi Malaysia (UTM), Malaysia and MAHSA University, Malaysia, and Shibaura Institute of Technology (SIT), Japan. The students who joined the gPBL were coming from different backgrounds which are electrical engineering, mechanical engineering, computer 
science, and industrial design. In addition, they did not have any experience in project-based learning before they joined the program, and they were first-year until third-year students.

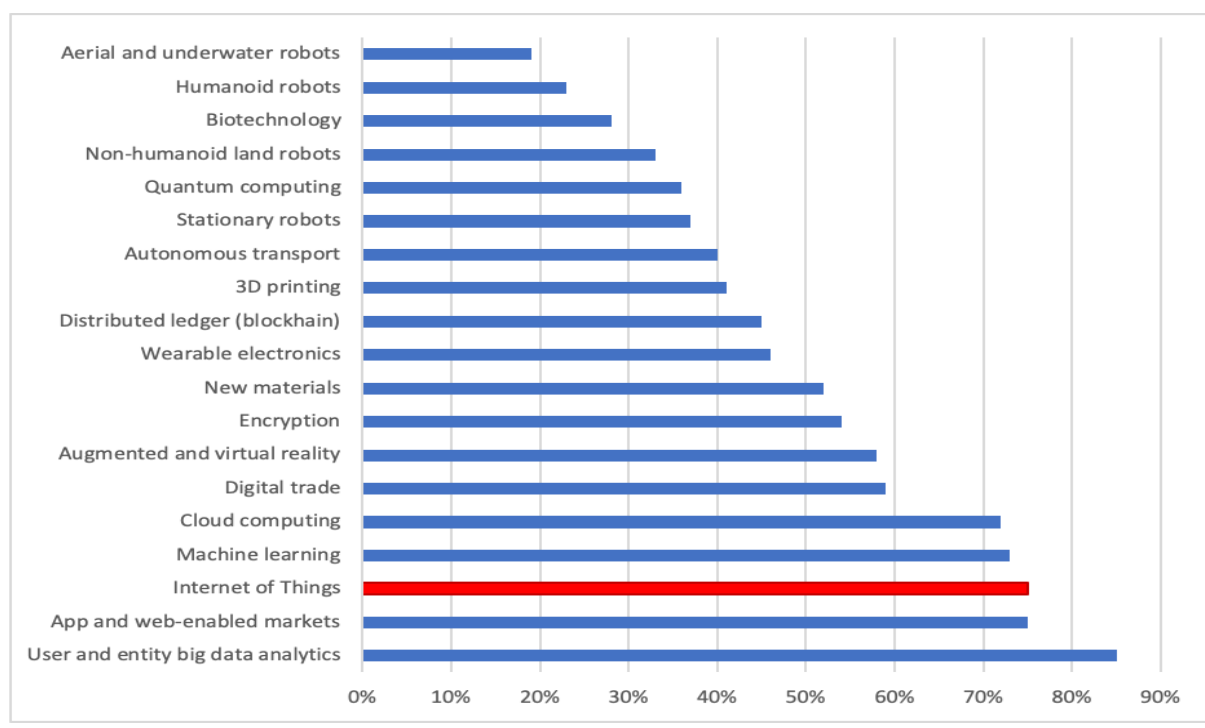

Fig. 1. Technologies by proportional of companies likely to adopt them by 2020 [14]

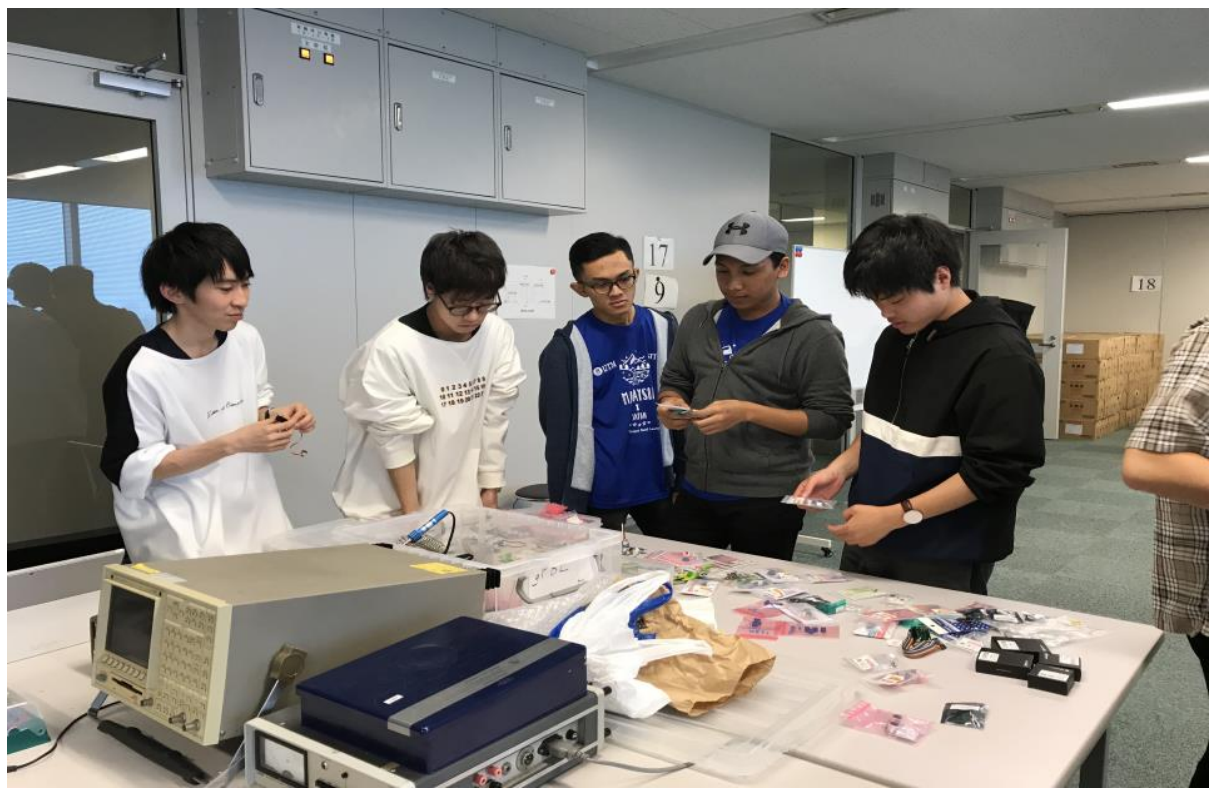

Fig. 2. Students identified what type of sensors and equipment available 
The students were asked to write a reflective journal daily throughout the program. Students were guided to write the reflective journal by answering:

a) What have you learned?

b) Any problem you are facing and how you solve it?

Each participant submitted five reflective journals, (RJ1-RJ5) at the end of the program. Thematic analysis [15]-[17] was used to analyze the reflective journals. They are six phases introduced in thematic analysis which are:

i. Familiarizing yourself with your data

ii. Generating initial codes

iii. Searching for themes

iv. Reviewing themes

v. Defining and naming themes

vi. Producing a report

\section{$4 \quad$ Results and discussion}

Based on thematic analysis, the final report of this study is presented in Table 2 [18].

From the findings, students experienced metacognitive skills throughout the program. The students were able to describe how they identify the problems to propose a project and identify the methods to complete the projects. They started with brainstorming with their team members. However, due to cultural differences, they need to find a problem that is suitable for both countries.

Other than that, language differences make them difficult to communicate. However, the students can overcome the problem by using Line, Google Translate, digital dictionary, and sign language.

\section{Conclusion}

Students were able to complete a project within five days in gPBL program. They learned a lot among themselves where this finding tally with the authors' observation during the program. gPBL encourages students to find information or method to help them completed the project, to plan since they have a very limited time, to monitor their project to make sure it is correct, to evaluate their task for any changes, and to apply what they have learned before. In a conclusion, gPBL promotes thinking and problem-solving skills, encourages students to work with peers in other fields, and encourages students to adapt to a new culture. 
Table 2. Final Report

\begin{tabular}{|c|c|c|}
\hline Themes & Sub Themes & Example of quotation \\
\hline \multirow{4}{*}{$\begin{array}{l}\text { Schema } \\
\text { training }\end{array}$} & Project understanding & We brainstormed few IoT projects that we want to do. \\
\hline & Identify problem & $\begin{array}{l}\text { First, we proposed to make a smart speed detector for cars. The } \\
\text { pattern of driving might be useful for the insurance company in } \\
\text { Malaysia. Unfortunately, in Japan, they already have a black box or } \\
\text { dash camera to prove the driver's innocence. }\end{array}$ \\
\hline & Technology & $\begin{array}{l}\text { Even some of them cannot speak proper English, we still can com- } \\
\text { municate with each other using translator apps and pictures from the } \\
\text { internet. }\end{array}$ \\
\hline & Communication & $\begin{array}{l}\text { We also ask help from sensei or assistant lecturers and they were } \\
\text { very helpful. }\end{array}$ \\
\hline \multirow{3}{*}{ Planning } & Self-responsibility & So, I do the design and coding for the servo motor. \\
\hline & Teamwork & $\begin{array}{l}\text { Shuu taught me about Arduino ESP32. He taught about the library } \\
\text { and setting in the Arduino software. }\end{array}$ \\
\hline & Project planning & After that, we separated the works. \\
\hline \multirow{4}{*}{ Evaluation } & Project modification & $\begin{array}{l}\text { Since we finished our coding, Wataru wanted to add up some sound } \\
\text { by using a buzzer to produce some noise when the reading triggered } \\
\text { to make it more attractive. }\end{array}$ \\
\hline & Problem-solving & $\begin{array}{l}\text { It was all because of a simple mistake, we identified each axis of the } \\
\text { sensor wrongly assigned where the } x \text {-axis is the y-axis. So, after that, } \\
\text { we combined the code for the triaxial acceleration sensor and the } \\
\text { pressure sensor without any problem. }\end{array}$ \\
\hline & Analyzing & $\begin{array}{l}\text { We used simple coding on Arduino to make sure our connection } \\
\text { between the microprocessor and components is connected correctly. }\end{array}$ \\
\hline & Decision making & $\begin{array}{l}\text { But we ended up using an ultrasonic sensor, speaker, LED, and at } \\
\text { first, we were discussing using apps to notify the user for the feed- } \\
\text { back but we discussed and due to short timing, we decided to use } \\
\text { email for the notification. }\end{array}$ \\
\hline \multirow{2}{*}{ Monitoring } & Project planning & $\begin{array}{l}\text { On the second day, we started to do a checklist/goals for things we } \\
\text { want to do throughout the day. }\end{array}$ \\
\hline & Time management & $\begin{array}{l}\text { I could manage my time properly so that I could maximize the } \\
\text { working time. }\end{array}$ \\
\hline \multirow{4}{*}{ Transfer } & Communication & Be open-minded and supportive are important for team works. \\
\hline & Time management & $\begin{array}{l}\text { On the last day, which was the presentation day, I made a big mis- } \\
\text { take because was late to the presentation room. I will not repeat this } \\
\text { mistake ever again. }\end{array}$ \\
\hline & Project planning & $\begin{array}{l}\text { I learned something from group } 5 \text { which was how there managed } \\
\text { their time and how they come out with a checklist idea. Throughout } \\
\text { this week, I can see the functionality of everyone in their group. So, I } \\
\text { thought they deserved to be a winner. }\end{array}$ \\
\hline & Teamwork & $\begin{array}{l}\text { In conclusion, teamwork, communication, and planning are im- } \\
\text { portant to make any project works. }\end{array}$ \\
\hline
\end{tabular}

\section{Acknowledgment}

This work is supported by UTM Technology and Innovation Management Sdn. Bhd. and RUG vote 4C458. 


\section{$7 \quad$ References}

[1] F. M. Reimers, C. K. C, and Hung, Teaching and Learning for the Twenty-First Century. Harvard Education Press, 2016.

[2] "global Project Based Learning (gPBL)," Shibaura Institute of Technology.

[3] Litvinova, T., Andriutsa, N. and Movchun, V. (2021). "Developing Students' Intercultural Communicative Competence through Online Learning,” Int. J. Emerg. Technol. Learn., vol. 16, no. 08, p. 162. https://doi.org/10.3991/ijet. v16i08.18947

[4] Yin, Z., Liu, Z., Zhang, Z., Chang, J. and Hu, X. (2021). "Experiences from a New Project-Driven and Outcome- Based Educational Concept in a Blasting Engineering Study Program," Int. J. Emerg. Technol. Learn., vol. 16, no. 08, p. 145. https://doi.org/10.3991/ijet.v16i08.21371

[5] Al-Abdullatif, A. M., Gameil, A. A., Hassa, A. and Arabia, S. (2021). "The Effect of Digital Technology Integration on Students ' Academic Performance through Project-Based Learning in an E-Learning Environment," Int. J. Emerg. Technol. Learn., vol. 16, no. 11, pp. 189-210. https://doi.org/10.3991/ijet.v16i11.19421

[6] Krajcik J. S. and Blumenfeld, P. C. (2006). "CHAPTER 19 PBL Kraichik," in The Cambridge Handbook of the Learning Sciences.

[7] Gibson, G. D. (2001). "Cognitive Literacy: A 21st Century Imperative for Education and Community Revitalization,”.

[8] Flavell, J. H., (1979). "Metacognition and cognitive monitoring: A new area of cognitivedevelopmental inquiry," Am. Psychol., vol. 34, no. 10, pp. 906-911. https://doi.org/10.1037/0003-066x.34.10.906

[9] Husamah, H. (2015). "Blended Project Based Learning: Metacognitive Awareness of Biology Education New Students," J. Educ. Learn., vol. 9, no. 4, p. 274. https://doi.org/10.11591/edulearn.v9i4.2121

[10] Aşık G. and Erktin, E. (2019). "Metacognitive Experiences: Mediating the Relationship between Metacognitive Knowledge and Problem Solving," Egit. ve Bilim, vol. 44, no. 197, pp. 85-103. https://doi.org/10.15390/eb.2019.7199

[11] Nett, U. E., Goetz, T., Hall, N. C., and Frenzel, A. C. (2012). "Metacognitive Strategies and Test Performance: An Experience Sampling Analysis of Students' Learning Behavior,” Educ. Res. Int., vol. 2012, pp. 1-16. https://doi.org/10.1155/2012/958319

[12] Brown, A. L., Bransford, J. D., Ferrara, R. and Campione, J. C. (1982). "Learning, Remembering and Understanding,".

[13] Rahimi M. and Katal, M. (2019). "Metacognitive strategies awareness and success in learning english as a foreign language: An overview," Procedia - Soc. Behav. Sci., vol. 31, no. 2011, pp. 73-81. https://doi.org/10.1016/j.sbspro.2011.12.019

[14] "The Future of Jobs Report 2018," World Economic Forum, 2018.

[15] Braun, V., \& Clarke, V. (2006). "Using Thematic Analysis in Psychology," Qual. Res. Psychol., vol. 3, no. 2, pp. 77-101.

[16] Maguire, M., \& Delahunt, B. (2017). "Doing a Thematic Analysis: A practical, Step-byStep Guide for Learning and Teaching Scholars," AISHE-J All Irel. J. Teach. Learn. High. Educ., vol. 9, no. 3, 2017.

[17] Bree R. and Gallagher, G. (2016). "Using Microsoft Excel to code and thematically analyse qualitative data: a simple, cost-effective approach.," vol. 8, no. 2.

[18] Ghazali, N. E. (2019). "Exploring Metacognitive Skills among Engineering Students through global Project-Based Learning (gPBL)". 


\section{Authors}

Nurzal Effiyana Ghazali is an Assistant Honorary Secretary, Society of Engineering Education Malaysia (SEEM) and Deputy Director at Universiti Teknologi Malaysia (UTM) Centre for Engineering Education (CEE). She is a Senior Lecturer at the School of Electrical Engineering, Faculty of Engineering, Universiti Teknologi Malaysia.

Khairiyah Mohd. Yusof is a President, Society of Engineering Education Malaysia (SEEM), and former director at Universiti Teknologi Malaysia (UTM) Centre for Engineering Education (CEE). She is on the Editorial and Advisory Boards of several journals, such as the ASEAN Journal of Engineering Education, Journal of Engineering Education, European Journal of Engineering Education, International Journal of Engineering Education, and Journal of Problem-based Learning (PBL) in Higher Education.

Fatin Aliah Phang is a member of, Society of Engineering Education Malaysia (SEEM). She is an Assistant Director at Universiti Teknologi Malaysia (UTM) Centre for Engineering Education (CEE) and Chair at School of Education, Faculty of Social Sciences \& Humanities, UTM. She received several national and international awards such as Okayama ESD Award (Global Prize) 2018.

Rashidah Arsat completed her Ph.D. at RMIT University, Australia in 2009. She is currently a Senior Lecturer at UTM. Her research interests mainly are surface acoustic wave devices, nanomaterial, sensor technology, and engineering education.

Nur Azliza Ahmad is a member of the Board of Engineer Malaysia (BEM) \& the Malaysian Board of Technologies (MBOT). She is an Electrical Engineering lecturer at MAHSA University. Her specialization in the research area is electromagnetics, nanotechnology, and antenna design.

Hiroaki Morino is a Professor at the Department of Information and Communications Engineering, Shibaura Institute of Technology (SIT), Japan. He is a member of the Institute of Electrical and Electronics Engineers (IEEE) and Institute of Electronics, Information and Communication Engineers (IEICE). He received the Outstanding Teacher Award at Shibaura Institute of Technology.

Article submitted 2021-06-15. Resubmitted 2021-07-21. Final acceptance 2021-07-22. Final version published as submitted by the authors. 